No. 6(57), 2018, pp. 91-105

https://doi.org/10.12797/Politeja.15.2018.57.06

\author{
Alvydas NIKŽENTAITIS \\ Lithuanian Institute of History in Vilnius \\ nikzentaitis@gmail.com
}

\title{
THE GRAND DUCHY OF LITHUANIA AND THE POLISH-LITHUANIAN COMMONWEALTH AS AN IDEOLOGICAL OUNDATION OF THE UNITY OF INTERMARIUM?
}

ABSTRACT The article surveys the question how the past of the Grand Duchy of Lithuania and the Commonwealth of Both Nations is used in region's cross-border issues, and the question could it be the ideological basis for the idea of the Intermarium is raised. The analysis of the countries of the region revealed that these themes in Lithuania, Poland and Belarus are basicaly used for the creation of the identity of the societies, however in any country these topics of the past are not dominating, moreover in Ukraine the theme of the Grand Duchy of Lithuania and the Commonwealth of Both Nations is in marginal position. The central position in the memory culture of these societies take the events of the 20th century. Obviously such secondory position of the understanding of the events of the past showed the commemoration of the anniversary of the Union of Lublin in Poland in 2009. The analysis of the historical research demonstrates different view. Evaluations of the historians in four countries do not differ so cardinally as it was before 1990. Such situation is as a signal that probably it is a time to think about the preparation of the general textbook for schoolchildren of four countries, or synthesis of the history.

Keywords: Memory culture, politics of history, historiography, The Grand Duchy of Lithuania, the union of Both Nations, the union of Lublin, the Constitution of May 3. 
7 he concept of Intermarium as a political doctrine of the Polish state has been re1 vived again at the beginning of the $21^{\text {st }}$ century. The doctrine rests upon a desire to create a union of states in the area of the Adriatic, the Baltic and the Black Sea as a power that could serve its interests in competition with Russia, and perhaps even with older member states of the European Union. As it is well known, the doctrine itself developed in the early $20^{\text {th }}$ century and is closely related to the figure of Marshal Józef Piłsudski, who alluded to the past in his schemes, with special emphasis on the Polish-Lithuanian Commonwealth. ${ }^{1}$

The marshal's schemes could not be carried out before World War II. Are they likely to succeed in the $21^{\text {st }}$ century? Let us leave those political ideas to politicians and focus on the question about the reception of the former Commonwealth in the societies that are its heirs and whether its image may turn out to be unanimously positive in the four main societies of the region and if it may be instrumental in building Intermarium in the $21^{\text {st }}$ century.

\section{THE PLACE OF THE GRAND DUCHY OF LITHUANIA AND THE POLISH-LITHUANIAN COMMONWEALTH IN THE CULTURES OF MEMORY OF BELARUS, LITHUANIA, POLAND AND UKRAINE}

The attitude of the communities inhabiting the territories of the former Grand Duchy of Lithuania and the former Commonwealth to the heritage of the state they shared is very varied. The Poles exhibit an annexationist approach to this legacy, which manifests itself in treating the Commonwealth as the First Polish Commonwealth. The Lithuanians, along with the Belarusians, identify only with the Grand Duchy of Lithuania before the Union of Lublin, whereas for the Ukrainians this state is a foreign one, even hostile in view of its wars against the Cossack Hetmanate, which in Ukraine is considered the precursor of the modern Ukrainian nation. And while the history of the Commonwealth is a very popular topic in the four countries, it has serious competitors in each. In Poland, as well as in Lithuania, the chief element of the culture of memory is the heroic struggle for freedom in the $20^{\text {th }}$ century; in Belarusian culture it is the partisan republic of the Great Patriotic War that occupies a more prominent place than the Grand Duchy of Lithuania. Another difference is in terms of the tradition of using the history of the former state as a basis for the cultures of memory. ${ }^{2}$ In Belarus it was not until the late $20^{\text {th }}$ century that the legacy of the Grand Duchy of Lithuania was discovered and in consequence it is not firmly rooted in the society. In Poland, on the other hand, the former Commonwealth plays the role of what may be referred to as history of the "third degree".

P. Okulewicz, Koncepcja "międzymorza" w myśli i praktyce politycznej obozu Józefa Pitsudskiego w latach 1918-1926, Poznań 2001.

A. Nikžentaitis, "Abiejų Tautų Respublikos ir Lietuvos Didžioji Kunigaikštystės praeitis lietuvių, lenkų, baltarusių ir ukrainiečių atminties kultūroje”, in Lietuvos istorijos metraštis (in press). 
This term indicates that that the history of the former Commonwealth was made subordinate to the present already in the early $20^{\text {th }}$ century and it served to maintain the identity of Poles and the Polish culture of memory, and this attitude is emerging again in the $21^{\text {st }}$ century in the reception of the interwar concepts. This is especially evident in such notions as "Intermarium" and the "Jagiellonian idea". Both these categories allude to the former Commonwealth, but their meaning has been filtered through appropriate interpretations which date back to the early $20^{\text {th }}$ century. It is only in Lithuania - and not in all cases - that the history of the Grand Duchy is history of the "second degree", which means that the past of this state was adapted to the needs of the present in the late $20^{\text {th }}$ and early $21^{\text {st }}$ century. One of the consequences of this is the respective attitudes that these countries exhibit towards the history of the Grand Duchy of Lithuania and the Polish-Lithuanian Commonwealth. In Belarus and Ukraine the past is not used as a justification for the foreign policy of the state. In Poland, the main function of the state's historical policy is to defend the Poles' good name against criticisms levelled at their $20^{\text {th }}$ century history. ${ }^{3}$ The common opinion in Lithuania in turn is that information warfare may target not only the history of Lithuania in the $20^{\text {th }}$ century, but also the Grand Duchy of Lithuania. For example, the State Security Department of Lithuania noted in 2014 that Russia was using in its information warefare such distant events as the battle of Orsha (1514). ${ }^{4}$ The differences indicated above demonstrate the problems that have to be solved in search of agreement regarding the past.

\section{HOW THE PAST IS USED IN INTERNATIONAL RELATIONS. THE THEORETICAL ASPECT.}

The past is an important instrument in international relations. Ignoring history may make it very difficult to understand relations between countries. Consequently, over the past twenty years there has been an increase in popularity - on a par with economic rationalism - of the theory of constructivism, which devotes far more attention to immaterial factors that shape international relations, such as stereotypes, national identity, etc. ${ }^{5}$ A great number of studies have been made within this theoretical framework. The theory of constructivism has been used as well in research on post-1989 Polish Eastern foreign policy. ${ }^{6}$ However, if constructivism is to be used in the discussion of issues surrounding the application of the culture of memory in international relations, its theoretical aspects have to be further developed and it should be supplemented with

At <http://www.lex.pl/czytaj/-/artykul/nowa-ustawa-poszerza-kompetencje-ipn>, 4 May 2017.

Lietuvos valstybès saugumo departamentas. 2014 mety veiklos ataskaita, p. 13, at < http://www.vsd.lt/ Files/Documents/635645217977365000.pdf>, 19 April 2016.

5 C. Weller, "Internationale Politik und Konstruktivismus. Ein Beipackzettel", in WeltTrends, no. 41 (2003/2004), pp. 107-123.

6 S. Gerhardt, Polska polityka wschodnia: Die Außenpolitik der polnischen Regierung von 1989 bis 2004 gegenüber den östlichen Nachbarstaaten Polens (Russland, Litauen, Weißrussland, Ukraine), Marburg 2007. 
propositions advanced within the theory of the culture of memory. Within this theory they are linked directly to issues of identity shaping. It is widely known that identity is most clearly manifested in the attitude of one's own group towards others. Yet, an important element of foreign policy is developing relations with others and justifying them. This justification depends on the adopted direction of policy. Theoretically, it might be suspected that a change in one's foreign policy towards another country is related to a transformation of the image of the "other", and in this way, to changes in the perception of one's own identity. Thus, in international relations, understood as interaction between us and them, the borderline between what is inside and what is outside disappears. Such an attitude to the problem makes it possible to understand how in the age of the internet even the blogs of prominent political figures (let us recall e.g. the Russian president's Dimitri Medvedev's thoughts on Stalinism and zero tolerance of crime) may become an important source for the description of the foreign policy of a given country. It appears that one of the reasons for the failure of earlier projects was that they were based on the false premise that the entire culture of a country is the object of foreign policy. Researchers have analysed the cultures of memory of particular countries as such and attempted to discover the role of these cultures in international policy and international relations. What was not given due consideration was the research of the Belgian political scientist, Valerie Rosoux, who fairly clearly determined the goals of using the past in foreign policy and suggested a structural approach to the analysis of this problem.

Analysing the use of the past in relations between Germany and France, Valerie Rosoux suggested three possibilities of how it may be utilised:

a) the past as a means of escalating the confrontation between countries,

b) ignoring the past; "history is left to historians",

c) transforming the past into contemporary memory, i.e. accepting the past for what it is. The author explais this claim by reference to the former French prime minister Lionel Jospin's words who claimed that such a stance does not require one to forget the past, but strives to make peace with it.

The latter possibility was chosen in the rapprochement between France and Germany and its outcomes were positive. At the international level both states managed to accept the existence of two different memories and at the same time to respect this difference. $^{7}$

One may add to the author's observations the research results obtained in the Scandinavian countries, where rapprochement is founded among others on the foregrounding of those issues from the past that the countries of the region share. While exceptions may be found, one can speak in this way of a fourth possibility in which the past may be used, whereby the revival of the common past is a means to achieve closer cooperation in the region. ${ }^{8}$

V.B. Rosoux, Les usages de la mémoire dans les relations internationales. La recours au passé dans la politique étrangère de la France à légard de l'Allemagne et de l'Algérie de 1962 à nos jours, Brüssel 2001.

$8 \quad$ P. Aronson, "National Cultural Heritage - Nordic Cultural Memory: Negotiating Politics, Identity 
Having presented all those theories, it is worth arguing that more beneficial to the countries of the former Commonwealth may be the Scandinavian experiences. The German-French model of using the past is not applicable in this case, since the past utilized for developing mutual relations had not been an element of the culture of memory either in France or in Germany. Whereas when it comes to Scandinavia, one has to take note of some historical parallels. Similar to Lithuania and Poland, closer ties between the three Scandinavian countries - Sweden, Denmark and Norway - were established as a result of a union treaty, namely the one signed in Kalmar (1397) in fact at the same time as the Act of Kreva (1385). The bond was not as strong in Scandinavia as in the case of Poland and Lithuania, and the union broke up definitively as early as in 1523. After the dissolution of the union the relations between the countries were not always friendly and it was not until the $19^{\text {th }}$ century that a new stage in their rapprochement began along with the spread of what was referred to as the doctrine of Pan-Scandinavianism, ${ }^{9}$ the central tenet of which was the idea that the Union of Kreva should serve as a model for the future of the region. According to one of the most renowned researchers of Scandinavia, Bernd Henningsen, Pan-Scandinavianism is nowadays the only $19^{\text {th }}$-century nationalist movement that has not lost its validity and is still relevant for the integration of the Scandinavian countries. Leaving the historical aspect aside, what has been essential in the rapprochement between the Scandinavian countries is the fact that the languages are genetically related, although this excludes Finland. In recent decades Nordic identity has been built predominantly on the basis of the present of these countries, particularly on emphasis on economical development and the welfare-state policies of the Scandinavian countries. Such a construction of Pan-Scandinavianism resembles, on the one hand, Germany in the period from the 1960s to 1980s, and on the other hand, the Soviet Union, since in both the myth of progress was an important constituent of respectively Germanness and Sovietness and their cultures of memory.

\section{THE POLISH-LITHUANIAN COMMONWEALTH AND THE GRAND DUCHY OF LITHUANIA AS AN OBJECT OF INTERNATIONAL POLICY}

A common past is one of the constituents of the international policy of the states that exist nowadays in the territories of the former Commonwealth, and therefore the Grand Duchy of Lithuania and the Polish-Lithuanian Commonwealth are sometimes mentioned in this context. For example, the Grunwald battlefield has become

and Knowledge", in B. Henningsen, H.K. Geisinger, S. Troebst (eds.), Transnationale Erinnerungsorte: Nord- und südeuropäische Perspektiven, Berlin 2009, pp. 71-90.

9 B. Henningsen, Die schwedische Konstruktion einer nordischen Identität durch Olof Rudbeck, at <https://www2.hu-berlin.de/skan/gemenskap/inhalt/publikationen/arbeitspapiere/ahe_09. html\#fn5>, 20 April 2016. 
a meeting place for the official representatives of the Polish and Lithuanian authorities. ${ }^{10}$ During their official visits to Ukraine, on the other hand, representatives of the Lithuanian government frequently stay in Lutsk, ${ }^{11}$ a place where the Grand Duke of Lithuania organized a meeting of many European monarchs in 1429. While analysing materials on how the history of the former Commonwealth is used in foreign policy, one cannot help but notice that historical events came into focus most prominently in 2007 when another anniversary of the May 3 Constitution was celebrated, in 2009 during the celebrations on the anniversary of the Union of Lublin as well as in the early $21^{\text {st }}$ century when the history of Cossackdom was commemorated. In order better to understand the processes of utilizing the past in relations between the countries of the region, it is worth looking more closely at those three events.

\section{a) The May 3 Constitution}

As a historical event that relates Lithuania and Poland, the May 3 Constitution was first used in such a context in 2001 at a meeting of the Lithuanian-Polish parliamentary assembly. First in Vilnius in February, the Lithuanian side suggested to their Polish colleagues that the anniversary should be celebrated jointly and in June of the same year, the Polish side extended this offer by proposing that May 3 should be celebrated in both countries. As it frequently happens, the idea was put into effect in the anniversary year but forgotten afterwards. It was only revisited six years later.

The context of the debates and an account of the debate over these issues, which took place between January 2007 and May 2008, are discussed in the analysis of the Lithuanian political scientist, Raimundas Lopata. ${ }^{12}$

The debate on the significance of the May 3 Constitution for Lithuania began as soon as a bill of the Seimas of the Republic of Lithuania was submitted according to which the anniversary of the May 3 Constitution was to be declared a national holiday in Lithuania. According to Lopata, the reason for such an intiative was an identity crisis in Lithuanian society as well as a crisis in foreign policy after Lithuania achieved its political goals three years earlier by joining the European Union and NATO. Therefore, after 2004 there were no longer any ideas that could become the main focus of interest for society. This is precisely why soon after 2004 discussions began over a conception of Lithuanian foreign policy whereby the country was to become an active participant in Eastern European regional politics. It was realised too that a Lithuania without allies cannot achieve much and therefore strategic relations with Poland came to be highly valued by the political elite of Lithuania. After a treaty was signed between the two countries in 1994, the suspicious attitude towards Poles disappeared owing to intensive

10 R. Petrauskas, D. Staliūnas, "Die drei Namen der Schlacht: Erinerungsketten um Tannenberg”, in M. Aust, K. Ruchniewicz, S. Troebst (eds.), Verflochtene Erinnerungen. Polen und seine Nachbarn im 19. Und 20. Jahrbundert, Köln-Weimar-Wien 2009, p. 136.

11 At <http://archyvas.lrp.lt/en/news.full/7267?prn=1>, 4 May 2016.

12 R. Lopata, "Šiuolaikinė politika ir istorijos datos: $1791 \mathrm{~m}$. Gegužès 3-osios Konstitucijos była”, in V. Sirutavičius, R. Lopata, „Lenkiškasis“veiksnys Lietuvos politikoje, Vilnius, 2011, pp. 43-113. 
collaboration between the political elites. One of the contributing factors here was largely the good personal relationship between the President of Lithuania, Valdas Adamkus, and President Aleksander Kwaśniewski and later President Lech Kaczyński. The idea of Lithuania as an important actor in Eastern politics once again revived the legacy of the Grand Duchy of Lithuania and along with it all matters related to the May 3 Constitution.

In 2007 in turn, the first symptoms of a conflict between Poland and Lithuania emerged. After Civic Platform won the election it became clear that only the Polish president was interested in maintaining good relations with Lithuania, whereas the government had other priorities in foreign policy. The earliest public clash between Lithuania and Poland occurred in May 2008, when Minister Radosław Sikorski criticized for the first time the attitude of the Lithuanian authorities towards the Polish national minority in Lithuania. ${ }^{13}$ This changing atmosphere in Polish-Lithuanian relations have to be borne in mind if one wants to understand why the initiative related to the May 3 Constitution developed in 2007.

The claim that the Lithuanian side was interested in maintaining good relations with Poland is confirmed by those who supported the idea of commemorating the May 3 Constitution in Lithuania. They included President Adamkus, Dalia Grybauskaite, and Lithuania's leading politicians representing various parties, including Vytautas Landsbergis, Andrius Kubilius, Česlovas Juršènas and others. The bill was supported by all representatives of the Lithuanian Ministry of Foreign Affairs. It had strong approval of the committee for foreign affairs of the Seimas, whereas in one of the most important votes on the issue within another parliamentary committee views were divided and the bill would not have been passed if not for the chairman of that committee. ${ }^{14}$

The reasons why the act regarding the May 3 Constitution was discussed for so long become clear if one analyzes the two opposing narratives regarding that event. The supporters of the May 3 Constitution celebrations saw in it, as well as in the entire history of Polish-Lithuanian relations, not only an example of good cooperation between the two countries, but also the source of Lithuania's Europeanness. The opponents in turn evaluated the constitution from the point of view of Lithuania's statehood. The main arguments against commemoration were claims that the constitution destroyed Lithuania's statehood and the actions taken by General Żeligowski and Piłsudski were only a continuation of processes that the constitution had initiated. Such an accusation forced the supporters of commemoration to change their tactics and to emphasize the October 20, 1791 act, i.e. the Mutual Pledge of the Two Nations. It was only along with this act that the May 3 Constitution commemoration day could be included in the list of national holidays in May 2008.

An important role in this entire discussion was played by the international aspect. On May 2, 2007 the first Lithuanian-Polish joint celebrations of the constitution took

13 At <http://www.delfi.lt/news/daily/lithuania/lenku-ministras-rsikorskis-izeide-lietuvius.d?id=16958301>, 27 April 2016.

14 R. Lopata, "Šiuolaikinè politika...". 
place. The event was organized simultaneously in Vilnius and in Warsaw and connection was established between the participants via TV. On the Lithuanian side, the celebration was attended by the President, the Speaker of the Parliament and on the Polish side, by the Speakers of the Sejm and the Senate, as well as the President of the European Parliament, Hans-Gert Pöttering, and presidents of the parliaments of Estonia, Hungary, the Czech Republic and Germany. ${ }^{15}$ The main message of the meeting was not only the commemoration of the European past of Lithuania and Poland, but also a declaration of adherence to the ideals of Europe in the future. One has to emphasize another important aspect of the celebrations, which was not mentioned at the time. They were organized also in order to demonstrate the international support for the advocates of the idea to commemorate the May 3 Constitution in Lithuania.

The last time commemorative celebrations for the May 3 Constitution were organized in Lithuania was on May 2, 2016. Polish-Lithuanian relations at that time had cooled due to a dispute over the status of the Polish national minority in Lithuania. As a consequence, only a modest delegation of Polish politicians attended the celebrations in Lithuania. The delegation was headed by Maria Koc, the Deputy Speaker of the Senate, i.e. a rank lower than at the earlier ceremonies of this kind. Present on the Lithuanian side were the Speaker of the Senate, the Minister of Foreign Affairs and the former President of Lithuania, Valdas Adamkus. Furthermore, a recording was played back of a speech by the President of the European Parliament, Martin Schultz. However, the speeches differed in content. Contrary to the previous two anniversaries, this time the politicians only spoke about the historical significance of the constitution. The only reference to the present was the stress on wise compromise, which could be understood as a remark aimed at the Polish side that the time had come to finish the disputes between the countries.

\section{b) Celebration of the $40^{\text {th }}$ anniversary of the Union of Lublin}

Another attempt to make use of the tradition of the former Commonwealth in international relations was made in 2009, when the anniversary of the Union of Lublin was celebrated in Poland. Just as it was the case in 2001, on the anniversary of the signing of the union a meeting was held in Lublin of the parliamentary assembly of the Sejm and Senate of the Republic of Poland, the Seimas of the Republic of Lithuania and the Verkhovna Rada of Ukraine. ${ }^{16}$ The most important part of the ceremony was held on July 1, 2009 in Lublin with the participation of the presidents of Poland, Lithuania and Ukraine. Belarus was represented by the chairman of the Supreme Council which proclaimed the country's independence in 1991. Also invited were the presidents of Latvia and Estonia but they did not arrive in Lublin. The key parts of the celebrations included an ecumenical prayer, the conferring of honorary doctorates of the Catholic

15 At <http://www.delfi.lt/news/daily/lithuania/lietuvos-ir-lenkijos-parlamentai-kartu-paminejo-1791-m-geguzes-3-iosios-konstitucija.d?id=13062630>, 27 April 2016.

16 At <http://www.kresy.pl/?zobacz/obchody-440-rocznicy-unii-lubelskiej>, 27 April 2016. 
University of Lublin to the presidents and the ceremony in the Litewski Square. Unlike in 2007, the speeches delivered by the presidents focused particularly on regional cooperation. This was especially evident in the speech by President Kaczyński. "In this uniting Europe, we need to act in unison - only then will we be respected," he emphasized. "Only together can we earn in a uniting Europe such esteem that matches our history, our tradition and our cultures." And he continued: "As part of this Europe we can be what we would like to be, but only and exclusively side by side with our Lithuanian, Ukrainian - and I think in the future, Belarusian - as well as Estonian and Latvian friends." ${ }^{17}$ Adopting a similar tone, President Adamkus emphasized the cultural achievements of the region of the Polish-Lithuanian Commonwealth, referring to Sarbiewski, Mickiewicz, Kościuszko, Słowacki and others. The President of Lithuania also mentioned other important events, such as the fall of communism in the late $20^{\text {th }}$ century, and finished with the motto: "From the Union of Lublin to the collapse of communism". ${ }^{18}$ References to the more recent past as well as the aforementioned problems, particularly of Polish-Ukrainian relations in the first half of the $20^{\text {th }}$ century, were also to be found in Lech Kaczyński's speech. And this is understandable, as one of the unofficial elements of the celebrations was Polish protests against Viktor Yushchenko's politics of memory, which, according to the protesters, rehabilitated the murderers of Volhynia. As we can see, in those celebrations the past of the former Commonwealth was confronted with more recent history. This element was introduced into the ceremony by the protesters.

\section{c) The Cossack issue and Polish cinematography}

Foreign policy may be carried out not only by politicians. This is very well illustrated by the case of the Polish director Jerzy Hoffman's 1999 film With Fire and Sword. The film falls into the trend towards reconciliation between Poland and its neighbours after the fall of communism in $1989 .{ }^{19}$ The history of its reception demonstrates again how significant a feature film may prove for international relations.

The concept of the film developed following conciliatory declarations between Poland and Ukraine in the 1990s, which referred not only to the events of the $20^{\text {th }}$ century, but also to the $17^{\text {th }}$-century Polish-Cossack wars. ${ }^{20}$ In order to contribute to the

17 At <http://www.prezydent.pl/archiwum-lecha-kaczynskiego/aktualnosci/rok-2009/art,9,730,prezy dent-obchodzimy-dzisiaj-440-rocznice-wielkiego-sukcesu-kilku-narodow.html>, 27 April 2016.

18 At <http://kultura.lrytas.lt/-12464451661246390759-v-adamkus-liublino-unija-buvo-stiprios-ir-ilgalaik\%C4\%97s-s\%C4\%85jungos-pavyzdys-atnaujinta.htm>, 27 April 2016.

19 R. Habielski, "Przeszłość w sferze publicznej i życiu kulturalnym 1989-2005 (obszary zainteresowań, interpretacje, nośniki)”, in P. Skibiński, T. Wiścicki M. Wysocki (eds.), Historycy i politycy. Polityka pamięci w III RP, Warszawa 2011, pp. 81-106.

20 This is discussed in the declaration of reconciliation signed by the Presidents of Poland and Ukraine in 1997: T. Blaszczak, "Tarp valstybingumo ir etniškumo. 1918-1939 m. laikotarpio interpretacijos ir atminties politikos konstravimas Lenkijoje, Lietuvoje, Baltarusijoje ir Ukrainoje”, in E. Aleksandravičius (ed.), Tautiniai naratyvai ir herojai Vidurio Rytu Europoje po 1989 m., Vilnius 2015, p. 309. 
rapprochement between Poland and Ukraine the Polish director chose Henryk Sienkiewicz's historical novel With Fire and Sword published in 1884. As is well known, in his novel Sienkiewicz depicted the Polish-Cossack wars in the $17^{\text {th }}$ century as a clash of civilizations in which the positive characters are Poles and the Ukrainians play the negative roles. Hoffman changed all these elements in his adaptation. First of all, he cast renowned Ukrainian actors as the main characters: Bohdan Stupka as Bohdan Khmelnytsky and Ruslana Pysanka as Horpyna. The Cossacks are presented in the film as true Ukrainians. In an attempt to challenge the stereotypes, both the main Polish character and Bohdan Khmelnytsky are depicted as statesmen and true knights in Hoffman's film. The ending of Sienkiewicz's novel was altered too: the film does not show the battle of Berestechko, which was lost by the Cossacks, but the narrator points to a common enemy of the Poles and the Ukrainians, namely Russia, which defeated both the Cossacks and the Polish-Lithuanian Commonwealth ${ }^{21}$

The film was positively received both in Poland and in Ukraine. ${ }^{22}$ On the other hand, the Russian response to it was Taras Bulba filmed in 2009, whose main message is well ilustrated in the following statement by the film's director: "Russia, Belarus and Ukraine are one nation." ${ }^{23}$ Finally, it is worth adding that the film was banned in Ukraine in $2014 .{ }^{24}$

The analysis of the three examples of how the past is used in international relations demonstrates an instrumental approach to problems of history. The past is only remembered on the occasion of various anniversaries, as evidenced by the Lublin celebrations of the $440^{\text {th }}$ anniversary of the Union of Lublin. This fact is not specific to the history of the Polish-Lithuanian Commonwealth, but rather a rule with reference to how the past is utilised in international policy. Analysis of other similar initiatives, and only those related to the $20^{\text {th }}$ century, produces the same results. ${ }^{25}$

The international character of celebrations commemorating historical events is occasionally used in internal politics, as it was demonstrated by the debate on the May 3 Constitution in Lithuania. Even successful attempts to utilise the past for the benefit of mutual relations (as in Hoffman's With Fire and Sword) had a limited effect on the audience. In later years the Ukrainians themselves made films about the Cossacks ${ }^{26}$ but

21 M. Aust, “Wojny kozackie w polskiej, ukrainskiej i rosyjskiej kulturze historycznej”, in A. Nikžentaitis, M. Kopczynski (eds.), Dialog kultur pamięci w regionie ULB, Warszawa 2014, pp. 251-252.

22 M. Aust, Polen und Russland im Streit um die Ukraine. Konkurrierende Erinnerungen an die Kriege des 17. Jahrhunderts in den Jahren 1934 -2006, Wiesbaden 2009, pp. 251-271.

23 At <http://rg.ru/2009/04/09/taras.html>, 28 April 2016.

24 At <http://www.unian.net/society/1024808-v-ukraine-zapretili-prokat-filma-taras-bulba.html>, 28 April 2016.

25 K. Wigura, Wina narodów. Przebaczenia jako strategia prowadzenia polityki, Gdańsk-Warszawa, 2011, pp. 93-104; Z. Gluza, "Ośrodek KARTA a kwestia wołyńska”, in A. Zińczuk (ed.), Pojednanie przez trudną pamięć - Wołyń 1943, transl. by I. Boruszkowska et al., Lublin-Wojsławice 2012, pp. 39-54, at <http://www.pk.org.pl/publikacje/pojednanie_przez_trudna_pamiec_wolyn1943.pdf>, 28 April 2016.

26 M. Aust, “Wojny kozackie...”, pp. 253-254. 
there were no indications that the message of Hoffman's film resonated with them. The most important result of the analysis above is the conclusion that the past of the former Commonwealth does not hold great emotional appeal and it fades in comparison to more current affairs, which is especially visible in the Lublin celebrations of the anniversary of the Union of Lublin in 2009. On this basis it may be claimed that the past of the Grand Duchy of Lithuania and the Polish-Lithuanian Commonwealth cannot provide an ideological foundation for the union of Intermarium. This is at least a conclusion that follows from the analysis of the cultures of memory in the region.

Does the same apply to historiography? I will attempt to answer this question in the final section of the current text.

\section{THE POLISH-LITHUANIAN COMMONWEALTH AND THE GRAND DUCHY OF LITHUANIA IN HISTORICAL RESEARCH}

In the study of the culture of memory the question frequently arises as to the role of professional historiography. At the beginning of the boom in research on "history of the second degree" there may have been authors who claimed that historians are not so much researchers of the past, as direct reators of the culture of memory, but these opinions were soon repudiated. More recently it has been a dominant view that while historians contribute to the formation of the culture of memory by emphasizing important historical events, they are not creators of it. Their very approach to the object of study is different. While creators of the culture of memory search the past for trends that might prove beneficial for the future, historians study objective historical events by taking into account the context of that time. On the other hand, historians do not live on a desert island and - frequently unwittingly - they perpetuate some cultural stereotypes in their research. This is especially likely if they make statements regarding topics which they themselves have not studied on the basis of the sources.

The differences in approach to the past between historians and creators of the culture of memory make it necessary to evaluate the opinions advanced in historiography of the four countries regarding the former Commonwealth.

While Polish historiography is occasionally considered annexationist in its approach to the former Commonwealth, ${ }^{27}$ one cannot say the same of those historians who specialize primarily in the issues concerning the Grand Duchy of Lithuania. Such historians as Juliusz Bardach, ${ }^{28}$ Henryk Wisner, ${ }^{29}$ Henryk Samsonowicz, ${ }^{30}$ Andrzej

27 R. Ritter, "Das Erbe der Republik beider Nationen. Geschichte eines Gründungsmythos in Ostmitteleuropa”, in Z. Krasnodębski, S. Garsztecki, R. Ritter (eds.), Last der Geschichte? Kollektive Identität und Geschichte in Ostmitteleuropa Belarus, Polen, Litauen, Ukraine, Hamburg 2008, p. 26.

29 H. Wisner, Unia. Sceny z przesztości Polski i Litwy, Warszawa 1988.

30 Por. H. Samsonowicz, "Wkład Europy Środkowo-Wschodniej do cywilizacji europejskiej”, Lithuania, vol. 2, no. 11 - vol. 3, no. 12 (1994), pp. 23-30. 
Zakrzewski ${ }^{31}$ and many others, point in their works to the federal structure of the Polish-Lithuanian Commonwealth, emphasizing the autonomy of each of its two constituents. Among the array of historians of similar persuasion one should also mention Jerzy Kłoczowski, ${ }^{32}$ who wrote works and inspired scholarly projects which may be compared to Jerzy Hoffman's legacy in Polish cinema. In a similar way to that director, Kłoczowski the historian did a lot to help remove from Polish historiography the kind of "historical imperialism" that Jerzy Giedroyc and Juliusz Mieroszewski demanded..$^{33}$

Lithuanian historiography, similar to that of Poland, is very diverse. One may find here nationalist texts, but in recent times they have fallen out of the mainstream. Analysing the debates over the May 3 Constitution, Raimundas Lopata pointed out that the communities of historians at Vilnius University, the Lithuanian Institute of History and to some extent at the Vytautas Magnus University in Kaunas spoke in defence of the May 3 Constitution. The only academic centre which defended the stance of Lithuanian pre-war historiography was Vilnius Pedagogical University. ${ }^{34}$ When evaluating Lithuanian historiography when it comes to the former Commonwealth it is worth emphasizing that in collaboration with Polish historiography it seeks to explain the model of civilisation that characterized the Grand Duchy of Lithuania, ${ }^{35}$ and it perceives the legacy of that state as a joint achievement of all of its four constituent nations. ${ }^{36}$

The situation is different in Ukraine. Alfredas Bumblauskas has pointed to the tradition of Ukrainian historiography according to which the Ukrainian side viewed the former Commonwealth and the Grand Duchy of Lithuania as foreign history. This notion was reinforced by Soviet historiography, which did not grant Ukraine or Belarus the status of countries with a history independent from that of Russia. ${ }^{37}$ However, in recent years the situation has changed considerably. Tomasz Stryjek divides Ukrainian historians into three groups which approach the history of the former Commonwealth in different manners:

1) Historians who are continuators of Soviet historiography in Ukraine;

2) Traditionalists, i.e. that group of historians who continue the line of historiography started by Mykhailo Hrushevsky;

3) Revisionists, whose focus is above all on the study of Western and Eastern (Byzantine) influences.

31 A. Zakrzewski, Wielkie Księstwo Litewskie (XVI-XVIII w.). Prawo, ustrój, spoteczeństwo, Warszawa 2013.

32 J. Kłoczowski, "Wprowadzenie: Unia Lubelska - nowe perspektywy i spojrzenia", in J. Kłoczowski, P. Kras, H. Laszkiewicz (eds.), Unia Lubelska i tradycje integracyjne w Europie Środkowo-Wschodniej, Lublin 1999, pp. 5-11.

33 J. Mieroszewski, Listyz Wyspy. ABC polityki „Kultury”, R. Habielski (ed.), Paryż-Kraków 2012, p. 387.

34 R. Lopata, "Šiuolaikine politika ir istorijos datos: $1791 \mathrm{~m}$. Gegužès 3-osios Konstitucijos byla", in V. Sirutavičius, R. Lopata, „Lenkiškasis“veiksnys Lietuvos politikoje, Vilnius 2011, p. 90.

35 E. Gudavičius, Lietuvos europejimo keliais: istorines studijos, Vilnius 2002, pp. 17-59.

36 A. Bumblauskas, Lietuvos Didžioji Kunigaikštija ir jos tradicija, Vilnius 2010, pp. 249-284.

37 A. Bumblauskas, G. Kirkiené, F. Šabuldo (eds.), Ukraina: Lietuvos epocha 1320-1569, Vilnius 2010, p. 7. 
In this last group Stryjek has observed an approach towards to the Commonwealth and the Grand Duchy of Lithuania which is an alternative to the one exhibited by representatives of the first and second groups and is positively predisposed towards the legacy of both the Grand Duchy of Lithuania and the Polish-Lithuanian Commonwealth. ${ }^{38}$

Still different is the situation in Belarus. After a short period of freedom, Belarusian historians, with minor exceptions, were entirely subordinated to state authorities and therefore their opinions may be easily demonstrated by analysing Belarusian history textbooks. Tatyana Ostrovskaya has observed different attitudes towards the past in different periods of Lukashenko's regime. The most recent changes were introduced after 2002 and had bearing on the content of history textbooks. Although the idea of Slavic (Orthodox) unity still pervades Belarusian historiography, the exceptionally negative attitude towards both the Grand Duchy of Lithuania and the Polish-Lithuanian Commonwealth is gradually disappearing from it. While the Union of Lublin, for example, is still unanimously criticized, there is a differece of emphasis when it comes to the 1596 Church Union. The most recent version of the history of Belarus resembles closely pre-war historiography of Lithuania, in which the key element was the Lithuanian struggle against the Poles in the name of maintaining Lithuanian identity. Nowadays, Belarusians do the same in the latest history textbooks and therefore they are less decisive in evaluating the Church Union, in that they do not only perceive it as a negative phenomenon but also as a chance to protect Belarusian identity in the struggle against Catholicism. ${ }^{39}$

The study of statements made in the historiographies of the four constituent countries of the former Commonwealth produces different results than the analysis of the cultures of memory. In recent decades in Lithuania, the stereotype according to which that period of Lithuania's statehood was seen as wasted has been defeated, in Ukraine a number of historians have emerged who follow in the footsteps of the Lithuanians when it comes to the assessment of the Polish-Lithuanian Commonwealth and Belarusan historiography has been developing, albeit very slowly, in this direction too. While such research results allow us to observe that the attitudes of the historians from the four countries tend to converge, this is not enough for us to claim that we are witnessing changes which will enable the Grand Duchy of Lithuania and the Polish-Lithuanian Commonwealth to become the ideological foundation of the unity of Intermarium. Historiography is not a culture of memory and does not have the power to influence national identity to such an extent. The fact that historians' opinions in the region converge indicates that the time has come at least to attempt to write a common textbook for the countries of the region.

38 T. Stryjek, "Das Bild des Großfürstentum Litauen und der Ryecypospolita in den Synthesen der nationalgeschichte der gegenwärtigen ukrainischen Historiker”, in Z. Krasnodębski, S. Garsztecki, R. Ritter (eds.), Last der Geschichte? Kollektive Identität und Geschichte in Ostmitteleuropa Belarus, Polen, Litauen, Ukraine, Hamburg 2008, p. 83.

39 T. Ostrovskaja, "Baltarusių istorinès atminties genealogija ir mokyklinio švietimo praktikos", in Istorijos politikos modeliai ir kryptys: Europos Sajungos, Lenkijos, Rusijos ir Baltarusijos istorijos politika, Vilnius 2014, pp. 263-265. 


\section{BIBLIOGRAPHY}

Aronson P., "National Cultural Heritage - Nordic Cultural Memory: Negotiating Politics, Identity and Knowledge", in B. Henningsen, H.K. Geisinger, S. Troebst (eds.), Transnationale Erinnerungsorte: Nord- und südeuropäische Perspektiven, Berlin 2009.

Aust M., "Wojny kozackie w polskiej, ukrainskiej i rosyjskiej kulturze historycznej", in A. Nikžentaitis, M. Kopczynski (eds.), Dialog kultur pamięci w regionie ULB, Warszawa 2014.

Bardach J., O dawniej i niedawnej Litwie, Poznań 1988.

Blaszczak T., "Tarp valstybingumo ir etniškumo. 1918-1939 m. laikotarpio interpretacijos ir atminties politikos konstravimas Lenkijoje, Lietuvoje, Baltarusijoje ir Ukrainoje", in E. Aleksandravičius (ed.), Tautiniai naratyvai ir herojai Vidurio Rytu Europoje po 1989 m., Vilnius 2015.

Bumblauskas A., Kirkienė G., Šabuldo F. (eds.), Ukraina: Lietuvos epocha 1320-1569, Vilnius 2010.

Bumblauskas A., Lietuvos Didžioji Kunigaikštija ir jos tradicija, Vilnius 2010.

Gerhardt S., Polska polityka wschodnia: Die Außenpolitik der polnischen Regierung von 1989 bis 2004 gegenüber den östlichen Nachbarstaaten Polens (Russland, Litauen, Weißrussland, Ukraine), Marburg 2007.

Gluza Z., "Ośrodek KARTA a kwestia wołyńska”, in A. Zińczuk (ed.), Pojednanie przez trudną pamięć - Wołyń 1943, transl. by I. Boruszkowska et al., Lublin-Wojsławice 2012, at < http:// www.pk.org.pl/publikacje/pojednanie_przez_trudna_pamiec_wolyn1943.pdf>

Gudavičius E., Lietuvos europejimo keliais: istorines studijos, Vilnius 2002.

Habielski R., "Przeszłość w sferze publicznej i życiu kulturalnym 1989-2005 (obszary zainteresowań, interpretacje, nośniki)", in P. Skibiński, T. Wiścicki M. Wysocki (eds.), Historycy i politycy. Polityka pamięci w III RP, Warszawa 2011.

Henningsen B., Die schwedische Konstruktion einer nordischen Identität durch Olof Rudbeck, at $<$ https://www2.hu-berlin.de/skan/gemenskap/inhalt/publikationen/arbeitspapiere/ahe_ 09.html\#fn5>.

Henningsen B., Geisinger H.K., Troebst S. (eds.), Transnationale Erinnerungsorte: Nord- und südeuropäische Perspektiven, Berlin 2009.

http://archyvas.lrp.lt/en/news.full/7267? prn $=1$.

http://kultura.lrytas.lt/-12464451661246390759-v-adamkus-liublino-unija-buvo-stiprios-ir-

-ilgalaik\%C4\%97s-s\%C4\%85jungos-pavyzdys-atnaujinta.htm.

http://rg.ru/2009/04/09/taras.html.

http://www.delfi.lt/news/daily/lithuania/lenku-ministras-rsikorskis-izeide-lietuvius.d?id= 16958301.

http://www.delfi.lt/news/daily/lithuania/lietuvos-ir-lenkijos-parlamentai-kartu-paminejo-

-1791-m-geguzes-3-iosios-konstitucija.d?id=13062630.

http://www.kresy.pl/?zobacz/obchody-440-rocznicy-unii-lubelskiej.

http://www.lex.pl/czytaj/-/artykul/nowa-ustawa-poszerza-kompetencje-ipn.

http://www.prezydent.pl/archiwum-lecha-kaczynskiego/aktualnosci/rok-2009/art,9,730,

prezydent-obchodzimy-dzisiaj-440-rocznice-wielkiego-sukcesu-kilku-narodow.html. http://www.unian.net/society/1024808-v-ukraine-zapretili-prokat-filma-taras-bulba.html. 
Kłoczowski J., “Wprowadzenie: Unia Lubelska - nowe perspektywy i spojrzenia”, in J. Kłoczowski, P. Kras, H. Laszkiewicz (eds.), Unia Lubelska i tradycje integracyjne $w$ Europie Środkowo-Wschodniej, Lublin 1999.

Lietuvos valstybès saugumo departamentas. 2014 metu veiklos ataskaita, p. 13, at http://www.vsd. lt/Files/Documents/635645217977365000.pdf.

Lopata R., "Šiuolaikinė politika ir istorijos datos: 1791 m. Gegužès 3-osios Konstitucijos byla”, in V. Sirutavičius, R. Lopata, „Lenkiškasis“veiksnys Lietuvos politikoje, Vilnius 2011.

Mieroszewski J., Listy z Wyspy. ABC polityki „Kultury”, R. Habielski (ed.), Paryż-Kraków 2012.

Nikžentaitis A., "Abiejų Tautų Respublikos ir Lietuvos Didžioji Kunigaikštystės praeitis lietuvių, lenkų, baltarusių ir ukrainiečių atminties kultūroje”, in Lietuvos istorijos metraštis (in press).

Okulewicz P., Koncepcja “międzymorza” w myśli i praktyce politycznej obozu Józefa Pitsudskiego w latach 1918-1926, Poznań 2001.

Ostrovskaja T., "Baltarusių istorinès atminties genealogija ir mokyklinio švietimo praktikos", in Istorijos politikos modeliai ir kryptys: Europos Sajungos, Lenkijos, Rusijos ir Baltarusijos istorijos politika, Vilnius 2014.

Petrauskas R., Staliūnas D., "Die drei Namen der Schlacht: Erinerungsketten um Tannenberg”, in M. Aust, K. Ruchniewicz, S. Troebst (eds.), Verflochtene Erinnerungen. Polen und seine Nachbarn im 19. Und 20. Jahrhundert, Köln-Weimar-Wien 2009.

Ritter R., "Das Erbe der Republik beider Nationen. Geschichte eines Gründungsmythos in Ostmitteleuropa”, in Z. Krasnodębski, S. Garsztecki, R. Ritter (eds.), Last der Geschichte? Kollektive Identität und Geschichte in Ostmitteleuropa Belarus, Polen, Litauen, Ukraine, Hamburg 2008.

Rosoux V.B., Les usages de la mémoire dans les relations internationales. La recours au passé dans la politique étrangère de la France à l'égard de l'Allemagne et de l'Algérie de 1962 à nos jours, Brüssel 2001.

Samsonowicz H., "Wkład Europy Środkowo-Wschodniej do cywilizacji europejskiej”, Lithuania, vol. 2, no. 11 - vol. 3, no. 12 (1994).

Stryjek T., "Das Bild des Großfürstentum Litauen und der Ryecypospolita in den Synthesen der nationalgeschichte der gegenwärtigen ukrainischen Historiker”, in Z. Krasnodębski, S. Garsztecki, R. Ritter (eds.), Last der Geschichte? Kollektive Identität und Geschichte in Ostmitteleuropa Belarus, Polen, Litauen, Ukraine, Hamburg 2008.

Weller Christoph, "Internationale Politik und Konstruktivismus. Ein Beipackzettel”, in WeltTrends, no. 41 (2003/2004).

Wigura Karolina, Wina narodów. Przebaczenia jako strategia prowadzenia polityki, Gdańsk-Warszawa, 2011.

Wisner Henryk, Unia. Sceny z przesztości Polski i Litwy, Warszawa 1988.

Zakrzewski A., Wielkie Księstwo Litewskie (XVI-XVIII w.). Prawo, ustrój, spoteczeństwo, Warszawa 2013.

Alvydas NIKŽENTAITIS is chief science researcher in the Lithuanian Institute of History (Vilnius). Scientific interests: the politics of memory culture and history in Central and Eastern Europe. 